\title{
Pasang Naik Dan Surut Kota-Kota Pantai Utara Jawa, Sebuah Model Kajian
}

nfn. Nurhadi

Keywords: cities, north coast of java, coastal, modelling, spatial, development

\section{How to Cite:}

Nurhadi, nfn. Pasang Naik Dan Surut Kota-Kota Pantai Utara Jawa, Sebuah Model Kajian. Berkala Arkeologi, 15(3), 87-91. https://doi.org/10.30883/jba.v15i3.677

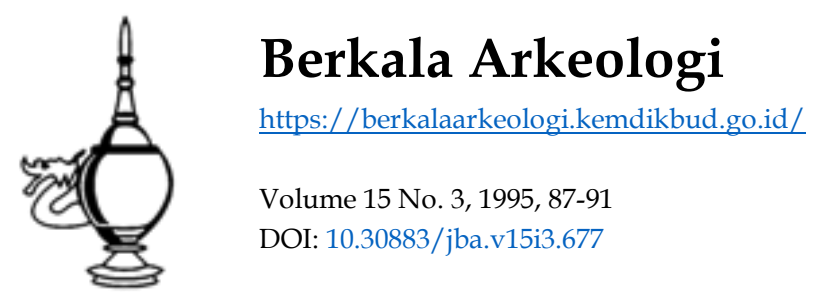

\section{(c) (1) (2)}

This work is licensed under a Creative Commons Attribution-NonCommercialShareAlike 4.0 International License. 


\title{
PASANG NAIK DAN SURUT KOTA-KOTA PANTAI UTARA JAWA, SEBUAH MODEL KAJIAN
}

\author{
Nurhadi \\ (Balai Arkeologi Yogyakarta)
}

I

Sajian ini didasarkan pada kerangka pemikiran yang struktural fungsionalistik; kota dicoba dipandang dari dua sisi, struktur internal dan fungsi eksternalnya. Kedua sisi ini merupakan kesatuan sistemik, dalam arti perubahan ataupun ketidak-layakan satu sisi akan mempengaruhi lainnya dalam tumbuh dan kelangsungan kota. Sebagai satuan himpunan masa yang cukup besar secara mikro kota merupakan organisasi sosial politik yang sangat kompleks, dalam arti, dalam masyarakat kota yang masif tersebut sebenarnya terbentuk dari sejumlah aglomerat manusia yang saling berbeda dan berlapis. Perbedaan ini diakibatkan sentimen budaya, bahwa manusia kota menempatkan diri mereka dalam persama-an dan perbedaan antara satu dan lainnya. Sedangkan pelapisan ditentukan atas jenjang kewenangan dalam perolehan materi, informasi dan hak dalam menentukan dan mengambil keputusan atas lainnya.

Kota harus tetap hidup dan berkembang; untuk itu diperlukan surplus dalam menjalankan fungsinya baik pada akses ekonomi yang didukung administrasilbirokrasi disamping kemampuannya untuk melakukan proses reproduksi dan produksi hilir dari pasokan wilayah penyangganya. Besaran lintas enerji, barang, manusia dan informasi yang melintasinya sangat menentukan besaran surplus yang diperoleh sesuai dengan efektivitas dan efisiensi dalam pelayanannya dalam lintasan tersebut. Untuk itu salah satu faktor yang perlu diperhitungkan dalam melihat pertumbuhan dan perkembangan suatu kota ialah ketepatannya dalam memilih tapak. Tidak setiap desa mampu mengembangkan dirinya menjadi suatu kota karena memang tidak layak untuk mengembangkan fungsi yang lebih tinggi, besar dan beraneka.

Dalam skala meso hubungan kota dengan penyangga ini masih dalam kategori internal, karena kota mampu tumbuh dan berkembang hanya karena terkondisi oleh kelayakan daya dukung wilayah belakangnya serta ketepatan pilih-an tapaknya. Kota pantai, bukan sekedar kota yang terletak di pantai, tetapi lebih dari itu, kota pantai haruslah memiliki fungsi kelautan. Laut dalam hal ini tidak dipandang sebagai faktor dis-torsi mobilitas, melainkan sebagai arena lintas enerji, barang, manusia dan informasi dari kota pantai satu dan lainnya. Pertumbuhan dan perkembangan kota pantai sangat ditentukan oleh mampu atau tidaknya kota tersebut menjalankan fungsi kelautannya. Dalam pemilihan tapak untuk mengembangkan pra-sarana kelautan terdapat beberapa persyaratan teknis, antara lain, yang pertama kelayakannya untuk prasarana labuh sarana mobilitas, yaitu perahu besar untuk laut lepas. Persyaratan pertama ini nyata terlihat dengan penempatan kota-kota pantai di muara sungai besar yang cukup dalam. Persyaratan yang lain, kota pantai tersebut harus memiliki wilayah belakang yang produktif untuk dapat dilintas . antar - pulaukan dalam kegiatan perdagangan. Dengan demikian kota pantai berfungsi sebagai entreport, yang menguasai wilayah penyangga dan sekaligus bertindak sebagai pintu keluarnya

\section{II}

Sejauh ini, secara sepintas kota-kota pan-tai utara Pulau Jawa khususnya yang terletak di bagian tengah dan timur menunjukkan struktur proses budaya yang serupa. Sesuai dengan fungsi kelautannya, kota-kota pantai tersebut tumbuh dan berkembang di lahan sekitar tepian muara sungai. Topografi Pulau Jawa tidak memungkinkan terjadinya sungai-sungai besar. Secara alami kualitas muara sungai sebagai prasarana kelautan terpelihara berkat gerusan air pasang-surut dan banjir tahunan. Peningkatan aktivitas ekonomi kota pantai pada awal perkembangannya ditandai dengan makin luasnya lahan dan kepadatan bangunan baik berupa sarana perumahan tinggan, pergudangan, maupun pertokoan/pewarungan ataupun yang berfungsi ganda

Proses nukleasi kota pantai diikuti pengembangan fungsi politiknya sebagai pusat birokrasi. Bangunan-bangunan pemerintahan menempati lahan yang lebih masuk ke dalam dengan arah hadap langsung ke pusat ekonomi Dengan demikian inti kota dapat diukur besarannya pada sumbu yang menghubungkan antara pusat ekonomi dan birokrasi tersebut. Pada umumnya pusat birokrasi menempati ruang yang lebih lapang khususnya untuk menempatkan regalia penguasanya. Hal ini tidak lepas dari fungsi 
simboliknya bahwa bangunan-bangunan tersebut merupakan adpertensi sosial kelas kota maupun wilayah.

Peningkatan aktivitas kota haruslah sejalan dengan pengendalian pengelolaan kota tersebut khususnya pada bagian yang mendukung fungsi ekonomi. Peningkatan aktivitas tanpa manajemen/pengelolaan yang baik dapat berakibat fatal dalam arti perkembangan tersebut dapat menjadi bumerang dengan menurunnya kualitas lingkungan muara sungai sebagai infrastruktur kehidupan ekonomi kota itu sendiri. Sebagai contoh pembuangan sampah yang tidak terkendali akan mengakibatkan pendangkalan alur muara.Gejala seperti ini dengan mudah dapat ditemukan di sebagian besar kota-kota pantai di kawasan tersebut.

Untuk mendukung kehidupan inti kota tersebut pada umumnya didukung dan dilingkari pemukiman penduduk yang berperan dalam pelayanan jasa, industri rumah dan kecil. Kelompok ini merupakan kelompok menengah-bawah yang cukup rentan pada perubahan kota baik pada sektor ekonomi maupun politik, karena ketergantungannya yang cukup besar pada kedua sektor.

Suatu gejala perubahan yang menarik perhatian pada kota-kota pantai utara Jawa ialah tumbuhnya pemukiman baru yang menempati lahan di luar lingkaran pemukiman menengah-bawah yang mengitari inti kota. Pemukiman baru ini mengambil jarak yang relatif agak jauh dan lebih lepas dari inti kota. Penataan jaringan jalan pada pemukiman baru ini jelas menunjukkan perencanaan tata kota yang jauh lebih baik. Pola linier pada bagian kota lama telah diganti dengan pola gridiron yang modern, hal ini dimungkinkan karena pemukiman baru menempati ruang yang semula kosong. Lingkungan seperti ini tentunya dapat memberikan kenyamanan tinggal dan mobolitas yang lebih baik dari pemukiman di bagian inti kota. Lahan yang semula kosong ini dibagi dalam petak-petak yang cukup luas untuk penempatan rumah induk yang besar (mansion) dengan pavilion dan bangunan pelengkap lain yang melingkarai sisi samping dan belakangnya serta taman di depannya.

Meskipun bangunan di lingkungan pemukiman baru ini memiliki tampilan yang saling berbeda tetapi secara struktural menunjukkan banyak kesamaan. Rancang bangun bangunan induk dan pavilion pada umumnya bercorak Eropa perantauan dengan tempelan ornamental yang tipikal Cina, Jawa, Arab, dan India. Maraknya unsur ornamental Cina pada pemukiman baru dapat disimpulkan bahwa sebagian besar pemukim di dalamnya adalah etnis Cina. Dari amatan arsitektural dan etno sejarah pemukiman baru ini tumbuh pada akhir abad ke-19 dan berkembang sampai dekade keempat abad ke-20. Beberapa bangunan yang terakhir menunjukkan rancang bangun yang lebih moderen, tidak simetris yang dalam istilah orang awam disebut "jengki" (yangkee). Berbeda dari sekulersisasi bangunan yang terjadi pada bagian inti kota, bangunan di pemukiman baru ini berfungsi simbolik sebagai adpertensi sosial-alat pamer untuk menunjukkan aktualisasi diri pemukimnya yang memiliki jenjang kemampuan perolehan materi yang sangat tinggi

Perubahan terakhir yang terjadi sampai saat ini. katakanlah sejak tahun 1940-an menunjukkan gejala arus balik, ditandai dengan surutnya penghunian dan alih fungsi bangunan pada bagian inti kota dan pemukiman baru. Bangunan yang berukuran besar-besar tidak dihuni lagi, kondisinya kumuh dan selanjutnya dimanfaatkan sebagai rumah burung walet. Hal ini mengisyaratkan telah surutnya peran penghuni inti kota dan pemukiman baru khususnya pada sektor ekonomi, yang menunjang kota sebagai pusat lintas barang dan enerji. Tumbuhnya bangunan perkantoran pemerintah pada awal masa orde baru menunjukkan telah terjadi pergeseran peran kota tersebut dalam skala meso dari sektor eko-nomi ke sektor administrasi dan birokrasi.

\section{III}

Secara formal sejak pemerintahan Gubernur Jenderal di sepanjang pantai utara pulau Jawa telah dikembangkan prasarana jalan darat yang memadai pada masa itu. Jalan darat tersebut merangkai semua kota-kota pantai dari Anyer sampai Panarukan. Mengingat masih terbatasnya teknologi pembangunan jalan darat pada masa itu untuk mengatasi muara-muara sungai yang lebar masih digunakan pos-pos penyeberangan (eretan) yang tentunya hal ini merupakan faktor distorsi. Secara teknis jalan darat tersebut me-motong daerah berrawa, guguk pasir, dan me-nyusuśri perbukitan sepanjang pantai. Dengan prasarana jalan darat ini mobilitas manusia, ba-rang, dan informasi antar kota makin meningkat.

Pengembangan jaringan kereta api (KA) baru dilakukan pada awal abad ke-20. Jaringan KA ini cenderung sejajar dan berimpit dengan jaringan jalan darat yang telah ada. Di samping itu jaringan KA yang memanjang menyusuri kota-kota pantai dikembangkan pula jaringan yang menghubungkan kota-kota pantai tersebut dengan wilayah pedalaman yang menyangganya. Secara ekonomis jaringan KA ini mendukung perkembangan kota-kota pantai, karena melalui jaringan tersebut arus barang komoditas yang memberikan surplus bagi kota-kota pantai akan 
lancar daiam frekuensi dan volume yang lebih besar, untuk selanjutnya di antara pulau-negarakan.

Antara kedua jaringan transportasi darat ini terdapat beberapa perbedaan yang cukup menyolok. Pada awal pengembangannya, KA mungkin merupakan sarana mobilitas yang lebih efi-sien karena meskipun dalam frekuensi yang ter-batas, $\mathrm{KA}$ mempunyai daya angkut yang lebih tinggi dari sarana otomotif, bahkan jauh lebih tinggi dibandingkan dengan sarana angkutan tra-disional - gerobak. Efisiensi tinggi ini memacu pengembangan jalur-jalur pendek yang menghubungkan kota pantai dengan wilayah pedalaman. Di sisi lain, pembangunan jaringan KA akan lebih selektif. Hal ini berbeda dengan pengembangan jaringan darat yang mampu menusuk masuk ke pelosok wilayah terpencil. Pengembangan jaringan $\mathrm{KA}$ ini juga memacu pertumbuhan kota-kota kecil di pedalaman yang dilewatinya yang berfungsi sebagai tempat transit barang untuk selanjutnya diangkut ke kota pantai.

Dengan pengembangan jaringan jalan darat dan KA mobilitas barang dan manusia akan semakin mudah, cepat, dan luas jangkauannya. Pilihan untuk menggunakan kedua jaringan ini tentunya didasarkan atas tingkat efisiensi dan efektivitas antara keduanya. Hal ini tentunya perlu diimbangi dengan kemampuan pelayanan yang dapat diberikan oleh kota-kota pantai. Dengan demikian persaingan antara kota pantai satu dan lainnya akan semakin terbuka dalam memberi-kan jasa pelayanan sebagai entreport.

Suatu gejala umum yang ditemukan pada masa kini ialah tidak berfungsinya lagi sebagian jaringan KA, khususnya jalur-jalur pendek yang menghubungkan antar kota pantai dan antar kota pantai dengan kota pedalaman. Penyusutan penggunaan jaringan KA secara dratis terjadi di sekitar dekade ke-7 abad ini. Sebagian besar jaringan KA tersebut terbengkelai tanpa upaya untuk diperbaiki atau di"hidup"kannya lagi. Lebih dari itu, sebagian besar jalur rel yang sejajar dan berimpit dengan jalan darat dibongkar dalam kegiatan pelebaran jalan darat. Bangunan stasiun besar ataupun kecil yang tidak berfungsi lagi telah dialihfungsikan menjadi sarana ekonomi, berupa pasar, pertokoan maupun sekedar deretan kios.

Dari pasang dan surutnya jaringan $\mathrm{KA}$ di kota-kota pantai ini menunjukkan bahwa pada akhirnya KA sebagai sarana mobilitas kalah bersaing dengan otomotif yang kemudian menjadi lebih ekonomis, bebas jadual dan mampu menelusuri jaringan pedalaman. Awal pengembangannya KA lebih efisien dibandingkan dengan sarana otomotif. Selanjutnya pengembangan jaringan jalan darat yang didukung dengan adanya sarana otomotif yang lebih efisien semakin memudah-kan mobilitas barang dari kota satu ke kota lain-nya. $\mathrm{Hal}$ ini dapat berakibat makin menajamnya persaingan antar kota pantai dalam memberikan pelayanan jasa transportasi lautnya. Kemampuan untuk bersaing tentunya harus didukung oleh kondisi lingkungan muara dan penguasaan teknologi untuk mengembangkan prasarana labuh, bongkar dan muat bagi sarana transportasi laut yang semakin berkembang pula teknologi dan ukurannya.

\section{IV}

Proses perkembangan dan ledakan kota-kota pantai tersebut di atas merupakan akibat kebijakan ekonomi makro Pemerintah Belanda memanfaatkan tingginya permintaan komoditas melalui tanam paksa dan liberalisasi ekonomi. Masuknya modal swasta memacu intensifikasi dan ekstensifikasi pertanian untuk komoditi eksport. Perkembangan sektor swasta serta merta meningkatkan mobilitas produk pertanian dari hulu ke hilir untuk selanjutnya dikirim ke luar. Momen-tum ini memungkinkan tumbuhnya raja-raja da-gang yang sebagian besar dikuasai cina dan selanjutnya berkembang sebagai elit orang kaya di kota-kota pantai.

Suatu hal yang menarik perhatian, meledak dan runtuhnya kota pantai tersebut sangat mungkin bukan hanya dikarenakan perubahan ekonomi global pada dekade ke-4 abad ke-20 ini; alasan lain berupa mal-fungsi kota dalam mengikuti perubahan dan perkembangan dunia teknologi transportasi laut yang tentunya menuntut peningkatan kualifikasi fasilitas yang tidak selalu dapat dipénuhi oleh setiap kota pantai. Revolusi transportasi darat terjadi pula sejak dikembangkannya jaringan KA yang menyusuri antar kota pantai dan menghubungkannya wilayah belakang. Ja-ringan KA tersebut sangat membantu dalam me-ngatasi faktor distorsi dalam mobilitas barang, enerji dan manusia sehingga lebih mudah berge-rak antar kota satu dan lainnya di Pulau Jawa. Dengan demikian persaingan antara kota satu dan lainnya akan lebih terbuka. Keterbukaan ini dipertajam lagi dengan perkembangan sarana otomotif -.bahwa ternyata peran otomotif pada perkembangan terakhir di tahun 1970-an telah pula memenangkan persaingan dengan $\mathrm{KA}$, yang dinilai lamban dan kurang iuas jaringannya

Sejauh ini perkembangan terakhir kota pantai yang tidak mampu melakukan diversifikasi fungsi tekno-ekonomis menjelang surutnya, bertahan sebagai pusat administrasi/birokrasi atas wilayah yang semula menjadi penyangganya. Lingkup mobilitas ekonomi yang lebih terbatas ini 
menjadi bahan pertanyaan: apakah realisasi otonomi Dati II dimungkinkan selama mereka tidak mampu memperoleh PAD (Pendapatan Asli Daerah) yang dapat mencukupi kebutuhannya untuk berdiri sendiri apalagi--- berkembang lebih besar lagi. Yang pasti, momentum seperti pada akhir abad 19 dan awal abad 20 tidak mungkin kem-bali lagi

Yogyakarta, Maret 1995

\section{LAMPIRAN 1}

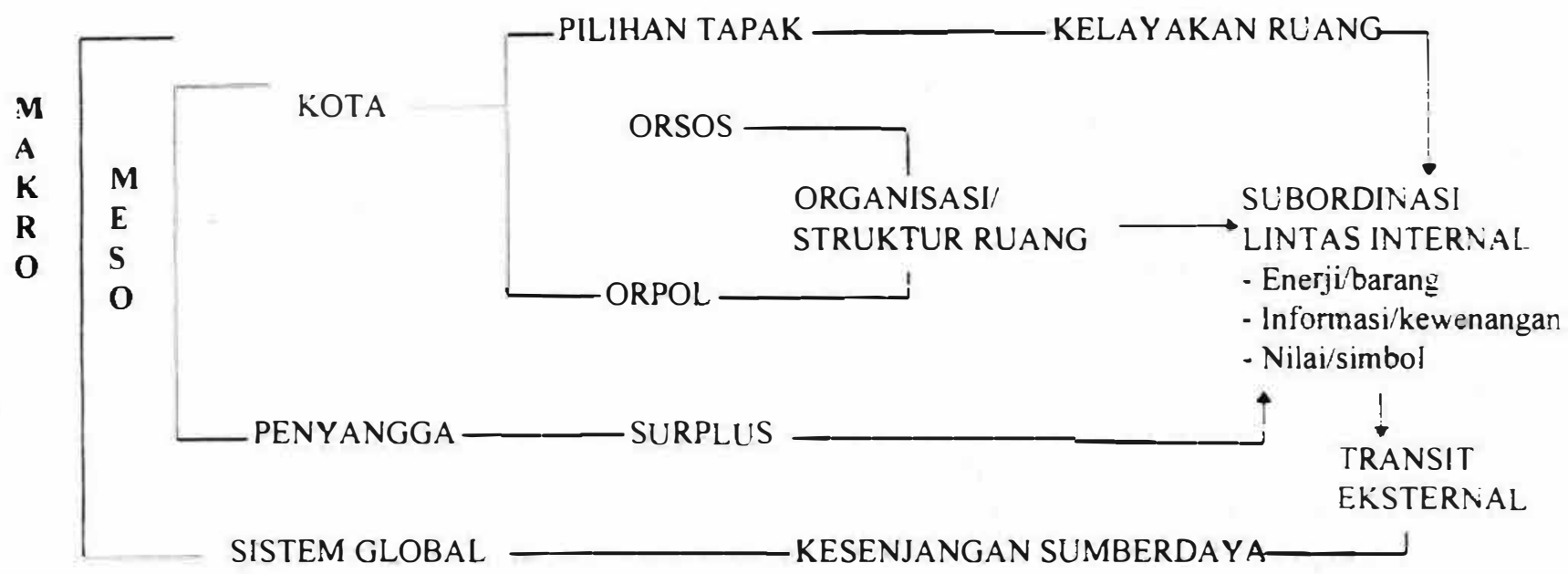

LAMPIRAN 2

\section{BUDAYA PERTANIAN}

SUMBERDA YA ALAM -

- Bentang

- Geologi

- Iklim

- Hidrologi

- Flora

- Fauna

KESENJANGAN SDA

- Keanekaragaman

- Kapasitas

- Kelentingan
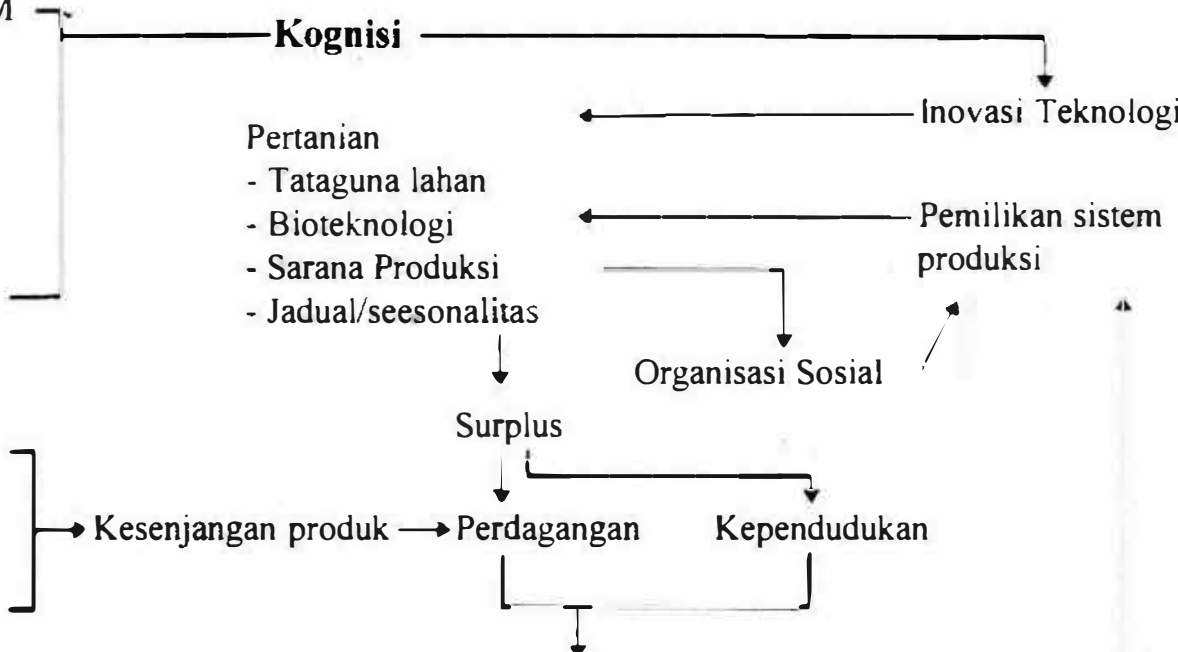

Gejolak tekno-sosial-ekonomi Struktur sosial

- Intensifikasi

- Diversifikasi

- Ekstensifikasi 


\section{LAMPIRAN 3}

\section{KOTA PANTAI, PERUBAHAN DAN PROSESNYA}

PENYANGGA

Sumberdaya alam

Sumberdaya budaya $\longrightarrow$ Kontribusi $\longrightarrow$ Kelayakan

Kontra-prestasi

Pernnintaan pasar

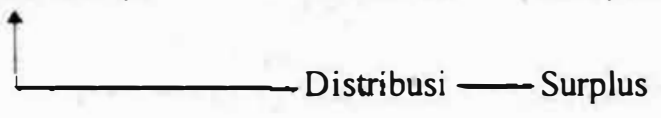

$\begin{aligned} \text { Kependudukan } \longrightarrow & \text { Perbedaan dan } \\ & \text { Pelapisan sosial }\end{aligned}$

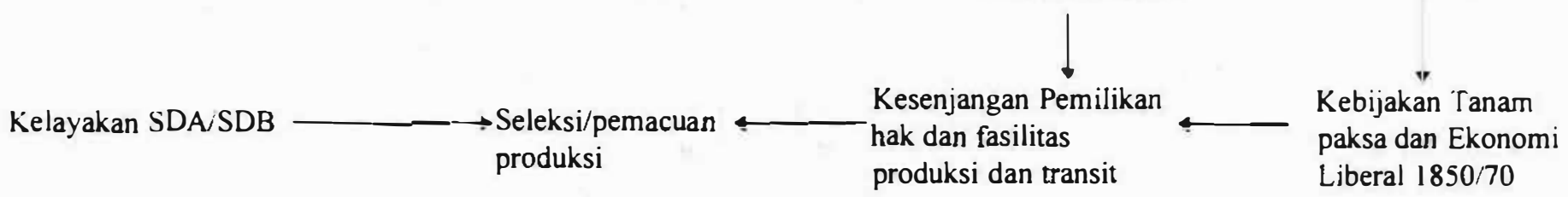

$\begin{array}{lll}\text { Dampak SDA } & \text { Intensifikasi } \\ \text { Hulu/hilr } & \text { Disersifikasi } & \text { Surplus } \longrightarrow\end{array}$
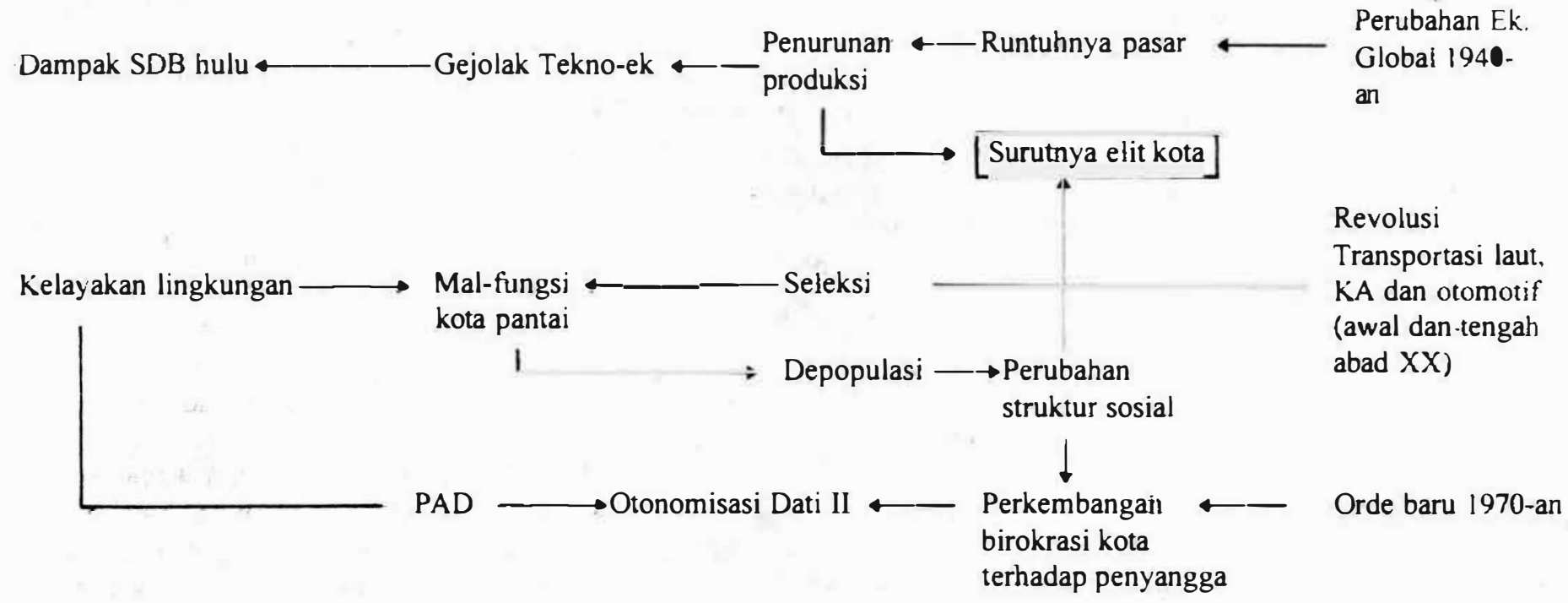